\title{
In search of an appropriate contemporary approach in Christian ethics: Max Weber's ethic of responsibility as resource
}

\begin{tabular}{|c|c|}
\hline \multicolumn{2}{|c|}{$\begin{array}{l}\text { Author: } \\
\text { D. Etienne de Villiers } \\
\text { 1,2 }\end{array}$} \\
\hline \multicolumn{2}{|c|}{$\begin{array}{l}\text { Affiliations: } \\
{ }^{1} \text { Department of Dogmatics } \\
\text { and Christian Ethics, Faculty } \\
\text { of Theology, University of } \\
\text { Pretoria, South Africa }\end{array}$} \\
\hline \multicolumn{2}{|c|}{$\begin{array}{l}{ }^{2} \text { Department of Philosophy, } \\
\text { Faculty of Humanities, } \\
\text { University of Pretoria, } \\
\text { South Africa }\end{array}$} \\
\hline \multicolumn{2}{|c|}{$\begin{array}{l}\text { Note: } \\
\text { Prof. Etienne de Villiers is } \\
\text { Emeritus Professor in the } \\
\text { Department of Dogmatics } \\
\text { and Christian Ethics, Faculty } \\
\text { of Theology, University } \\
\text { of Pretoria and acting } \\
\text { head of the Department } \\
\text { of Philosophy, Faculty of } \\
\text { Humanities, University of } \\
\text { Pretoria, South Africa. }\end{array}$} \\
\hline \multicolumn{2}{|c|}{$\begin{array}{l}\text { Correspondence to: } \\
\text { Etienne de Villiers }\end{array}$} \\
\hline \multicolumn{2}{|c|}{$\begin{array}{l}\text { Email: } \\
\text { etienne.devilliers@up.ac.za }\end{array}$} \\
\hline \multicolumn{2}{|c|}{$\begin{array}{l}\text { Postal address: } \\
65 \text { Brooks Street, Brooklyn } \\
\text { 0181, Pretoria, South Africa }\end{array}$} \\
\hline \multicolumn{2}{|c|}{$\begin{array}{l}\text { Dates: } \\
\text { Received: } 21 \text { Mar. } 2015 \\
\text { Accepted: } 15 \text { May } 2015 \\
\text { Published: } 31 \text { Aug. } 2015\end{array}$} \\
\hline \multicolumn{2}{|c|}{$\begin{array}{l}\text { How to cite this article: } \\
\text { De Villiers, D.E., 2015, 'In } \\
\text { search of an appropriate } \\
\text { contemporary approach in } \\
\text { Christian ethics: Max Weber's } \\
\text { ethic of responsibility as } \\
\text { resource', HTS Teologiese } \\
\text { Studies/Theological Studies } \\
71(1), \text { Art. \#2948, } 8 \text { pages. } \\
\text { http://dx.doi.org/10.4102/ } \\
\text { hts.v71i1.2948 }\end{array}$} \\
\hline \multicolumn{2}{|l|}{ Read online: } \\
\hline 口itar & $\begin{array}{l}\text { Scan this QR } \\
\text { code with your } \\
\text { smart phone or } \\
\text { mobile device } \\
\text { to read online. }\end{array}$ \\
\hline
\end{tabular}

Author:

D. Etienne de Villiers ${ }^{1,2}$

Affiliations: of Theology, University of

Pretoria, South Africa

partment of Philosophy, University of Pretoria,

South Africa

Note: Department of Dogmatic and Christian Ethics, Faculty of Philosophy, Faculty of Humanities, University of retoria, South Africa.

\section{Correspondence to}

Email:

Postal address:

65 Brooks Street, Brooklyn

Dates:

Accepted: 15 May 2015

How to cite this article De Villiers, D.E., 2015, 'In search of an appropriate contemporary approach in Christian ethics: Max Weber's Studies/Theological Studies 71(1), Art. \#2948, 8 pages. http://dx.doi.org/10.4102/ hts.v71i1.2948

\begin{abstract}
The article addresses the question: 'To what extent can Max Weber's ethic of responsibility be a helpful resource in the search of Christian Social Ethics for an appropriate contemporary approach'? This question is addressed by, first of all, providing a summary of Weber's famous speech Politics as a Vocation in which he developed his view on the ethic of responsibility; secondly, providing an interpretation of his view; and, thirdly, critically discussing the extent to which this ethic can serve as a resource for Christian Social Ethics in its search for an appropriate contemporary approach. The conclusion is that although some aspects of Weber's view on the ethic of responsibility are unacceptable to Christian Social Ethics, the core of it is commendable. Some of the implications of incorporating an ethic of responsibility approach in Christian Social Ethics are also briefly discussed.
\end{abstract}

\section{Introduction}

What are the features of an appropriate ethical approach to public issues in the contemporary context of late-modernity? This is one of the crucial questions Christian Social Ethics faces today. Instead of trying to answer this question by comparing and evaluating existing Christian social ethical theories, I rather take another approach by addressing the question: 'To what extent can Max Weber's ethic of responsibility be a helpful resource in the search of Christian Social Ethics for an appropriate contemporary approach?' Not only did Weber provide an incisive and still influential sociological analysis of the origins and features of Western modernity, but he also presented his ethic of responsibility as an ethical approach better attuned to modernity than the prevalent one of the ethic of conviction. Since then this ethic has increasingly become a topic of discussion in philosophy and theology. Philosophers like Hans Jonas, Karl Apel and Emmanuel Levinas and theologians like Dietrich Bonhoeffer, H. Richard Niebuhr, Ulrich Körtner and William Schweiker all developed their own versions of the ethic of responsibility.

In the article, I would like to make out a case that in spite of the fact that some aspects of Weber's view on the ethic of responsibility are unacceptable to Christian Social Ethics, the core of this ethic is commendable. In order to do this a brief summary of Weber's presentation of the ethic of responsibility in his famous speech Politics as a Vocation will first be provided. Then my own interpretation of this ethic will be provided, followed by a critical discussion of the extent to which it could serve as a resource for Christian Social Ethics in its search for an appropriate contemporary approach.

\section{Summary of 'Politics as a vocation'1}

In the first almost two thirds of Politics as a Vocation Weber provides a comprehensive sociological sketch of the political context in his time in which those students who strive to become professional politicians would have to work. He then in the last part of the speech turns to more personal advice on the qualities that such a professional ought to possess.

He distinguishes three qualities that are pre-eminently decisive for a politician: passion, to be understood as passionate commitment to a 'cause', a sense of responsibility in service to the 'cause' as lodestar in all political action, and judgement, the ability to maintain one's inner composure 
whilst being receptive to realities. In the possession of these three qualities lies the 'strength' of political 'personality', in his opinion.

He also addresses the relation between politics and ethics. He takes as his starting point the fact that different politicians strive to fulfil different causes. The nature of these causes the politicians seek to serve by striving for and using power is a question of faith. This does not, however, answer the question:

What vocation can politics per se, quite independently of its goals, fulfil within the overall moral economy of our conduct in life? Where is what one might call the ethical home of politics?

According to Weber (1994), we find two opposite views regarding the relation between politics and ethics. The one is that they have nothing to do with one another, the other that political action is subject to the same ethic as every other form of activity. Although he does not want to exclude ethics from politics, he is not convinced that one can uphold the thesis that any ethic in the world could establish substantially identical commandments applicable to all relationships. Concerning politics, one should ask:

Can the fact that politics operates with a quite specific means, namely power, backed up by the use of violence, really be a matter of such indifference as far as the ethical demands placed on politics are concerned? (Weber 1994:357)

He demonstrates his point by showing how politically absurd it would be to apply some of the absolute moral imperatives of the Sermon on the Mount directly to political action.

The difference between the absolutist ethics of the saint and the ethics of the politician is that consequences are of no concern to the first, whilst the second takes the consequences of the actions that are taken seriously. That, to Weber, is the crucial point. We have to understand that ethically orientated activity can follow two fundamentally different, irreconcilably opposed maxims:

It can follow the 'ethic of principled conviction' (Gesinnung) or the 'ethic of responsibility'... [T] here is a profound opposition between acting by the maxim of the ethic of conviction (putting it in religious terms: 'The Christian does what is right and places the outcome in God's hands'), and acting by the maxim of the ethic of responsibility, which means that one must answer for the (foreseeable) consequences of one's actions. (Weber 1994:358)

Weber emphasises that no ethics - including the ethic of conviction - can get around the fact that the achievement of 'good' ends is in many cases tied to the necessity of employing morally suspect or even morally dangerous means, and that one must reckon with the possibility or even likelihood of evil side effects. Nor can any ethic in the world determine when and to what extent the ethically good end 'sanctifies' the ethically dangerous means and side effects. The ethics of conviction is bound to founder hopelessly on this problem. The only position it can logically take is to reject any action that employs morally dangerous means.
At the end of his speech, Weber concedes that the convictionmoralists are right in insisting that politics is not something done with the head alone. This is even true of the person acting in accordance with the ethics of responsibility. It

... is immensely moving when a mature person (whether old or young) who feels with his whole soul the responsibility he bears for the real consequences of his actions, and who acts on the basis of an ethic of responsibility, says at some point, 'Here I stand, I can do no other'. That is something genuinely human and profoundly moving ... In this respect, the ethic of conviction and the ethic of responsibility are not absolute opposites. (Weber 1994:367-368)

\section{An interpretation}

I take as framework for interpreting Weber's ethic of responsibility his deep concern that the ethical dimension of human existence is under threat in the Western world because of modernisation.

Weber had a purely formal understanding of what it means to live ethically. To live ethically for him means to consistently and in a committed way shape your own life, in other words your own actions and character, in accordance with ultimate values, which may be quite different from those of another person. Doing this implies for him also accepting self-limitation, subordinating the satisfaction of natural desires and needs to the demands of devoting yourself to these ultimate values. Living ethically thus inevitably for Weber includes an ascetic element (two letters of Weber in Baumgarten 1964:398-399, 644-648; cf. Goldman 1988:116118; Schluchter 1996:36-39; 56-59; 62-69; Weber 1968:132).

It is the ethical dimension of life understood by Weber in this way that has, in his opinion, increasingly come under threat in modernity. The first threat resulted from the fact that a common Christian ethics has increasingly lost its dominance in the Western world since the Reformation, especially as a result of what he calls 'disenchantment' (Entzauberung). Processes of especially instrumental rationalisation have gradually undermined the belief that God and his commands have the highest authority, not only in religion, but also in other spheres of life. Not only has this led to the emergence of a plurality of divergent ethical systems, both religious and secular, but also to pluralism, that is the differentiation of autonomous and secularised social spheres, with distinctive value systems, which are in Weber's view in conflict with one another (Weber 2004:238, 244). This does not only force the individual to choose her own ultimate values from the offering of conflicting values, but also makes it difficult for her to find common ethical ground with other individuals (Weber 1949:18, 1968:508-509). It is even more difficult for someone who acts within the context of social spheres, for example, a politician, to find acceptance of his ultimate values amongst other role players.

The second threat to the ethical dimension of life relates in Weber's opinion to the fact that the freedom the individual has for ethical living has been decreased as a 
result of instrumental rationalisation. Weber was especially concerned that the on-going bureaucratisation of politics was diminishing the room the political leader has to achieve his ultimate values. He regarded the fact that specialised bureaucrats were virtually in charge of government decisions in Germany during the reign of Wilhelm II as a very negative development (Weber 1958:320, 1994:324-330). Bureaucrats tend to regulate government decisions purely in terms of technocratic considerations. In the last stage of his life he was convinced that the only way to break the grip of bureaucrats in government was to introduce a system of plebeian democracy, which would enable a leader with charisma to convince the voters of political goals based on his ultimate values and be directly elected by them. The mandate the elected leader received from the voters would then allow him to push through effective policies that would ensure the achievement of his political goals.

Weber's criticism of politicians who acted in accordance with an ethic of conviction in 'Politics as a vocation' must be seen against this background. They believed that they could apply their ethical convictions and achieve their ultimate values, encapsulated in their religion or political ideology, their Weltanschauung - to use Weber's inclusive designation - without making allowance for the distinctive nature and rules of politics, including the rule that the state may legitimately make use of violence under certain conditions. This means that they were either blind to the increasing differentiation of politics and other social spheres and the pluralism of value systems involved with it, or chose to ignore it because they regardless believed that they could still achieve their ultimate values by just turning up the intensity of their ethical convictions. In other words, they believed that an absolutist or fundamentalist approach - to use a contemporary term - would enable them in the end to achieve their ultimate values.

Weber found such an approach irresponsible. He was willing to admit that the adherents of an ethic of conviction do exhibit a narrow responsibility in committing themselves to particular ethical convictions. They were, however, irresponsible in a more comprehensive sense. First, they were irresponsible with regard to the values they recognised. They ignored the distinctive functional values and rules of politics and they did not really commit themselves to the successful achievement of their ultimate values. In spite of the fact that their approach goes against the grain of developments in modern societies, they stubbornly believed that they just have to stick diligently to their ultimate values to ensure their eventual achievement. Secondly, they were irresponsible with regard to the process of decision-making. They made political decisions without taking into account the foreseeable consequences of their actions, especially not taking into account that actions that strictly comply with their ethical convictions could have very negative consequences. In addition, they did not recognise that sometimes morally suspect or dangerous means are necessary to achieve political goals based on ultimate values. Weber was of the opinion that such an irresponsible approach to politics could only cause havoc in modern societies, because it is not attuned to modern conditions and should thus be abandoned.

As Weber regarded an ethic of conviction approach in politics both inappropriate and dangerous, he in Politics as a Vocation proposed the ethic of responsibility as a more appropriate approach. His ethic of responsibility is an ethic that takes responsibility as its lodestar. It is an ethic that is through and through qualified by responsibility. With responsibility, Weber did not so much have retrospective responsibility in mind. The guiding question of retrospective responsibility is:

- Who is responsible for this negative or positive outcome?

- Who should be blamed or praised for the outcome?

The responsibility that he had in mind should rather be understood as 'prospective responsibility' that has as guiding question:

- Who is responsible to do what to ensure a good outcome in future?

Applied to politics:

- Who is responsible to do what to ensure a good outcome in politics?

This question can also be subdivided into two questions:

- What should responsibly be done to ensure a good outcome in politics?

- Who is responsible to do that?

Weber's answer to the first question is to first identify what responsibly should be done in selecting values in the ethical execution of politics. To select ultimate values responsibly the politician should in his opinion not just blindly take any ultimate value based on her worldview and apply it to politics. She should rather select ultimate values that are attuned to the political situation at a particular point in time. She should, Weber urged, amongst others, be open to the calling of history of a particular nation at that particular point of time - as he puts it in some of his political writings (cf. Roth 1984:495; Weber 1958:14, 24, 140). The political leader should also responsibly take into account the particular nature of politics as an autonomous social sphere and recognise the values and rules that form part of it; for example, whatever her worldview is, she should acknowledge that the use of power, including the use of violence, is regarded as a legitimate means in politics. It is the responsibility of the politician acting in accordance with the ethic of responsibility to select the combination of ultimate values she finds appropriate and translate it into political goals and policies that will guide her political actions. It is, however, also her responsibility to not only pay lip service to the political goals she has set, but to diligently and effectively strive to attain them. When the political costs of achieving certain goals prove to be too high it is her responsibility to critically reflect on the goals and the ultimate values on which they rest, and to decide to adapt them, or - after due consideration - decide to remain faithful 
to them even if at that point in time there seems to be no possibility of achieving them.

It is secondly also important that the politician adhering to an ethic of responsibility should responsibly make ethical decisions in politics. Her first responsibility is also in this regard to take the concrete political situation seriously and to thoroughly analyse it in order to identify options for action, reliably estimate the foreseeable future consequences of different options for action and to establish which options for action and available means would contribute the most effectively to the achievement of the set political goals. Responsibly making ethical decisions in politics in the end also entails weighing the different options for actions and means and not shying away from making difficult decisions. When, for example, the only way to achieve a political goal is to use morally suspect or even dangerous means, or the political costs of refusing the use of such means are much higher than the costs involved with using them, the political leader should have the courage to take a decision and bear the responsibility for it.

Weber's answer to the question, 'Who is responsible for ensuring a good outcome in politics?', is that it is in the first place the responsibility of the strong charismatic political leader. ${ }^{2}$ All the other political role players have only limited responsibilities. Weber especially denies the responsibility of bureaucrats to set political goals and to decide on political action. Their role responsibility is rather to meticulously execute what the political leader expects them to do, even if it goes against their own ethical convictions. In that way they also, albeit in a limited way, contribute to a good outcome in politics (Weber 1994:330-331).

It is clear from this reconstruction of Weber's ethic of responsibility that he never intended it as a new and alternative first-level normative ethical theory. His focus in Politics as a Vocation is not on the identification of first-level ethical principles and their justification. He rather takes it for granted that every political leader already has his own ethical convictions based on his own worldview. For Weber all ultimate values are faith-based. There is in his opinion no way to rationally demonstrate that one's own ethical convictions ought to be universally accepted. It is also clear that Weber takes it for granted that each of the differentiated social spheres, including politics, has its own set of recognised functional values and rules that has crystallised over time. He is also not in Politics as a Vocation entering into a critical discussion about the nature of such values and rules.

Apart from the fact that Weber did not in any way try to demonstrate that 'responsibility' is the foundational first-level principle of the new ethic of responsibility, responsibility in any case cannot function as a first-level foundational

2.Wolfgang Mommsen (1989:33) remarks that "under the influence of the developments taking place in Germany ater 1918 he [Weber] was convinced that an effective democratic order and, in a broader sense, a free society were simply an effective democratic order and, in a broader sense, a free society were simply not possible without great leaders who would act out of their own sense of persona responsibility'. principle of ethics. The German philosopher Kurt Bayertz has in my opinion convincingly argued that responsibility can only function as a second-level principle. Whether it is used in a retrospective or prospective sense it always presupposes a first-level principle (Bayertz 1995:65-66). I can only be accused of being morally responsible for a certain negative outcome if it can be shown that I transgressed a recognised moral principle or norm. Moreover, I am only morally responsible to ensure a positive outcome if a moral principle or norm is provided in terms of which I ought to strive to attain the positive outcome. The only logically consistent way in which one can thus claim that an ethic of responsibility is a normative ethics is to regard it as a secondlevel normative ethics that is not providing guidance on firstlevel moral ethical principles, but rather guidance in dealing with recognised moral and non-moral principles or values and their application in ethical decision-making. In my opinion that is precisely what Weber had in mind when he proposed the ethic of responsibility as the appropriate ethics for politics.

\section{A model for an appropriate contemporary approach to Christian Social Ethics?}

I would like to pose that Weber's ethic of responsibility could serve to Christian ethicists as a model for doing social ethics early in the 21st century. Although adaptations and improvements are needed, Christian Social Ethics in our time is in need of the second-level ethic of responsibility approach for its emphasis on responsibly dealing with both values and ethical decision-making.

Weber introduced the ethic of responsibility mainly to counter the prevalent threats to the ethical dimension of human existence in particularly politics, whilst not ignoring irreversible developments in modernity like the proponents of the ethic of conviction did, but fully acknowledging them. In our time, the ethical dimension of human existence is also, if not more, under threat.

For one, the two threats to the ethical dimension that formed the backdrop of his ethic of responsibility proposal are still present today. Although the process of state bureaucratisation has turned out differently than Weber anticipated, the process of rationalisation, of which it is part, has in many respects diminished the freedom of individuals to live an ethical life, and especially to exert an ethical influence on broader societal developments (cf. Müller 2007:141). To mention just one example: the economy in its neoliberal capitalist guise has increasingly claimed to be exempt from ethical guidance. Those involved in business find it difficult to do business in accordance with their own ethical values and even more difficult to ensure the adherence of their companies to ethical values. As a result of the imperialist influence of economic values such as materialism, consumerism and competition on family and personal life, individuals also find it difficult to even in their 
private lives live consistently in accordance with the ethical values of their religion or view of life.

As a result of not only the diminishing influence of religion in the lives of people, but also of cultural globalisation, the diversity of ethical belief systems in modern societies is even more pronounced than at the time of Weber. It is not only that we find increasing numbers of groups professing different views of life, but also that within one religious denomination, even within one family, people have different views with regard to ethical issues. This makes cooperation within personal relationships, groups or broader society difficult when it comes to joint initiatives based on ethical values.

Attempts of present-day religious fundamentalists to counter these threats show a strong resemblance to the inadequate attempt of the proponents of an ethic of conviction to do so in Weber's time. They try to salvage the adherence of their group members to their 'thick' or strong ethical beliefs in a globalised world by completely ignoring irreversible global societal changes, isolating their members from the influence of contemporary cultural developments and reverting to authoritarian practices of times gone by. At the core of this response to modernisation lies the same sort of ethical absolutism that Weber found wanting in his time, and which in our time could only cause havoc in the world society.

I do not want to denigrate efforts in academic ethics to find agreement on a first-level normative theory that would help us to identify and justify ethical principles that are deemed universally valid. With Weber and postmodern philosophers as far apart as Richard Rorty and Alisdair MacIntyre I am, however, of the opinion that the claim that timeless first-level moral principles that are universally valid could be rationally identified and justified in a neutral manner that transcends cultural and religious traditions cannot be substantiated. Normative ethical efforts to identify and justify first-level moral principles are largely only meaningful within the framework of a particular view of life, such as liberalism, or a particular religion, such as Christianity. Such efforts should, in my opinion, be supplemented by an attempt to find the best way to deal directly with the existing value diversity, not only academically, but also in real life ethical decisions. What we pre-eminently need today is a second-level normative ethics that would provide guidelines on the best approach in dealing with the existing diversity of ethical values and intrasystemic values and on the measures that should be taken to ensure effective ethical decision-making. Weber provides us in his ethic of responsibility with a helpful model of such a second-level normative ethical approach.

However, his approach is ridden with a number of serious problems and should thus be adapted and improved. He, first of all, devised his ethic of responsibility for the social sphere of politics and, more specifically, for the political leader. Being solely applicable to the political leader and not to other role players in politics, it is an elitist and to some extent also an authoritarian approach. What we need - also in Christian Social Ethics - is a second-level normative ethical approach that would be applicable to all spheres of life and to all role players involved. To expect the bureaucrat as Weber does - to unconditionally accept and execute the political decisions of the political leader, even when they go against his deepest ethical convictions, is not acceptable from an antiauthoritarian, moral perspective. Weber also over-emphasises the conflicting nature of different value systems. Even the ethical value systems of competing views of life to some extent overlap. Otherwise, it would not have been possible for religions - and secular views of life - to take over ethical values from one another as all of them have done in the course of history. It is also not true that the value systems of different social spheres are always or in all respects in conflict with one another. For the most part the values they consist of are rather complementary to one another. Otherwise, it would not have been possible for a good politician to also be a good artist, or a good Christian to also be a good businessperson.

In my opinion, the most serious problem with Weber's version of the ethic of responsibility is that it is based on a purely formal understanding of ethics. To live your life consistently in accordance with self-chosen ultimate values - whatever the nature of these ultimate values - is for him to live an ethical life, or to use his own terminology, to be a personality. This formal understanding logically allows any cultural conviction, even if it is of an extreme nationalist or racist nature, to be elevated by the individual to an ultimate and thus ethical value. There is nothing that prevents the proponent of Weber's ethic of responsibility to subordinate values that have been recognised as moral in his own tradition (e.g. the Western tradition) to non-moral cultural or functional values or to even eliminate such moral values completely when making political decisions. In his own political writings of a personal nature, Weber himself did not shy away from propagating German nationalism with an imperialistic flavour as the ultimate political value to which all other values, including moral values in the traditional Western sense, are subordinated. In a letter written to Freiburg colleagues in November 1911, he went so far as to assert that he already in his inaugural address as professor in economics at the university of Freiburg in 1995 'very deliberately emphasized that politics is not and can never be a profession with a moral foundation' (Weber 1975:411; author's italics).

No doubt, such subordination and elimination of moral values like justice, honesty and peace from political decisionmaking would be very unacceptable from the perspective of Christian Social Ethics. One can even put it this way: Christian Social Ethics would regard it as irresponsibly dealing with values to define ethics in such a way that any personal conviction could be named ethical if it is chosen by someone as ultimate value. It would rather emphasise that certain substantive moral values should still have priority in public life in general and in politics in particular. Does this 
now mean that Christian Social Ethics should reject Weber's responsibility ethic proposal out of hand and revert to the conviction ethic approach that he denounces as inadequate in modern societies?

In my opinion, such a reversal back to a conviction ethics approach would only be unavoidable if on the one hand the responsibility ethic approach necessarily entails the denial of any validity of moral values in social spheres such as politics and the economy or, on the other hand, Christian Social Ethics in a panmoralistic manner insists on the absolute priority of 'thick' or strong Christian moral values and denies the validity of non-moral cultural and functional values in these social spheres. There is no reason to conclude that the responsibility ethic approach necessarily excludes any recognition of the validity of moral values in social spheres such as politics and the economy. As long as the validity of typical economic and political values, thus of functional values, and of cultural values contributing to the identity of a particular group is also recognised and no absolute priority is given to moral values, moral values can, without any contradiction, have a place in politics and the economy. This leaves us with the question: can Christian Social Ethics accept the de-absolutising of strong Christian values in politics and the economy and thus recognise the validity of functional political and economic values and cultural values?

It cannot be denied that for maybe the greatest part of the history of Christianity strong Christian moral values based on the Bible had absolute priority in all spheres of life. On account of the recognition of the absolute priority of biblical moral values functional economic and political values and cultural values were for the most part ignored, even rejected by theologians and replaced by biblical moral values. For more than a millennium the biblical prohibition against usury (Dt 23:19), for example, was used to condemn all imposition of interest, even after it became clear that the imposition of interest is an economically desirable practice. Today Christian Social Ethics has to acknowledge that functional and cultural values are, for the most part, not in opposition to moral values, but as valid in their own right stand to them in a complementary relationship. It is faced with the challenge to facilitate between the moral, functional and cultural value systems in such a way that they are all accommodated optimally (De Villiers 2012).

This is not to deny that functional and cultural values can sometimes be in strong opposition to moral values that are central to Christians. This is, for example, the case when functional values, which are valid in a particular social sphere, start to play an imperialistic role in other social systems. A valid economic value like competition can cause havoc if it becomes dominant in the family. For this reason, William Schweiker is of the opinion that the role of moral and religious values over against other values is primarily a limiting one: to prevent them from claiming validity outside their sphere of competence (Schweiker 2000:128-139). Schweiker seems to imply that the difference between moral and other values lies in the fact that moral values have transsystemic validity, whilst other values only have intrasystemic validity. If he is right, the trans-systemic nature of moral values may be one way of conceiving their relative - not absolute - priority with regard to other values. Their priority comes into play not only when functional and cultural values overstep the limits of their sphere of competency, but also when perverted versions of them become prevalent within social systems. For example, even in business the 'dog eats $\mathrm{dog}^{\prime}$ interpretation of competition is never acceptable from a Christian moral perspective. In other words, the priority of moral values consists - at least partly - in the fact that they play an indispensable limiting role with regard to the application of other values, both on the borders of social systems and within them (De Villiers 2012). One could possibly add that the priority of moral values - besides this limiting role - also consists in the guiding role they can and should play in economic and political projects. Economic and political projects should always strive to contribute optimally to morally improved societies, that is, societies that are more just and peaceful and in which human and nonhuman life on earth is better protected than previously.

If a responsibility ethic approach is followed Christian Social Ethics would recognise that on account of the pluralist and secular nature of most modern states distinctive strong Christian moral values could only to a limited extent serve as the normative basis for ethical guidance on public issues. It is of course quite possible and also desirable for Christian Social Ethics to provide ethical guidance to individual Christians on their personal behaviour in different social spheres - in the family, sport, politics and business - on the normative basis of strong Christian moral values. Christian Social Ethics should also take strong Christian moral values as point of departure when it provides ethical guidance to church denominations and ecumenical organisations on a Christian vision for a particular national society or the global society and on the prophetic witness they should have on specific societal issues. Of course, when doing this Christian Social Ethics should take full cognisance of non-moral values that are also at stake and strive to accommodate optimally such non-moral values in the ethical guidance that is provided.

However, in my opinion Gerrit de Kruijf has convincingly argued that the church, and one could add, Christian Social Ethics, cannot suffice with providing ethical guidance to individual Christians on their behaviour in public and with devising Christian visions of society based on strong Christian moral values (De Kruijf 1994:183, 195). As he puts it, the church and Christian Social Ethics should not only think once when it comes to public issues, but twice. When it comes to exerting influence on broader society with regard to the ethical stance that should be taken on a particular public issue, or when particular legislature is promoted as preferable from an ethical perspective, Christian Social Ethics has to think differently. In other words, when it comes to the exertion of ethical influence on non-Christians, Christian Social Ethics has to take a different approach. It has 
to translate its views into language that can be understood by non-Christians and to present arguments on the basis of moral values that are shared by non-Christians.

However, is it possible to find moral values that are shared by Christians and non-Christians? Moreover, is it acceptable for Christian Social Ethics to base its arguments on public issues on such shared moral values? It is not possible to adequately deal with these two important questions in this article. I just want to make one remark with regard to the first question. Although there is not widespread overlapping consensus on the positive moral obligations over against fellow human beings, there is at least widespread agreement amongst representatives of different ethical worldviews that the negative moral principle of harm avoidance ('do no harm') should guide interaction between all human beings (cf. Shapcott 2010:47). As a result, of the fact that all human beings share the same physical, psychical and, for the most part, also social nature and needs and can suffer in a number of easily identifiable ways, there is also rather widespread moral consensus on the actions that can cause harm and should be avoided. Kurt Bayertz asserts that today in at least Western societies there is general agreement that directives that prohibit hurting, killing, stealing from and cheating other people and tell us to keep promises, make out the core of such generally accepted moral obligations (Bayertz 2004:37-39). When it comes to positive moral obligations chances are better to reach adequate consensus within smaller social units such as families, civil organisations, business corporations and cultural groups, than in comprehensive social units such as national societies and the global society. This does not, however, rule out the possibility of also reaching agreement on at least certain positive moral obligations in national societies and the global society.

\section{Conclusion}

In the light of my criticism of Weber's version of the ethic of responsibility, I would like to plead for the adoption by Christian Social Ethics of a second-level ethic of responsibility approach that would avoid the problematic aspects of his version. This adoption is needed to ensure an appropriate ethical approach to public issues in the contemporary context of late-modernity. This is not the time and place to provide a detailed exposition of what such a contemporary ethic of responsibility approach in Christian Social Ethic entails. At the end of my article, I would like to give only a brief outline of some of the topics that would, in my opinion, have to be dealt with when following such an approach. I have already indicated that the two main foci of Weber's ethic of responsibility that should be retained are: dealing responsibly with values in accordance with the prevalent situation and making ethical decisions responsibly.

In our time, dealing responsibly with values, inter alia, entails:

- Dealing responsibly with the diversity of moral beliefs, not only in society, but also in organisations, as well as the differentiation of social spheres or systems with their respective and distinctive value systems. It involves, in my opinion, recognising the validity of intrasystemic functional values whilst retaining the relative priority of a minimal morality on which adequate agreement has been reached. It also involves tolerance of those who adhere to moral belief systems different from one's own, the de-absolutising of one's own moral beliefs and the willingness to critically examine one's own ethical beliefs in the light of the agreed upon minimal morality and to learn from and be corrected by others, including those who do not share one's religious beliefs. It, in addition, involves the obligation to seek the optimal moral agreement in all social circles one is involved in, and to promote the conclusion of moral covenants. Lastly, it involves the recognition that different people operating in a particular social system, but even more so operating in different social systems, have different role responsibilities, each based on different and sometimes unique combinations of specific functional and moral values. This alone implies that Christian Social Ethics should take a stand against all forms of panmoralism, which take as point of departure that conduct should only be guided by moral considerations.

- In contemporary societies we are, as a result of rapid technological development, faced with the emergence of an increasing number of new ethical issues for which we do not always have adequate and applicable moral values that can assist us in evaluating these issues and moral norms that can provide ethical guidance on how to proceed. There is often an ethical backlog when it comes to technological development. An ethics qualified by responsibility - including Christian Social Ethics - should, in my opinion, strive to overcome this ethical backlog by also taking on the responsibility to formulate or create new moral values and norms needed in this regard. This is where Christian Social Ethics could possibly make an important contribution. The philosopher Jürgen Habermas recently admitted that the liberal morality prevalent in Western societies is too poor or 'thin' to provide adequate ethical guidance on ethical issues involved in genetic engineering. He expressed the opinion that Christian morality, which is rich and 'thick', could help to provide the normative tenets that is needed (Habermas 2002:162, 2005:115).

With regard to the other focus of a contemporary ethics of responsibility, namely making ethical decisions responsibly, I only want to mention that the German theologian Eduard Tödt has already done ground-breaking work in identifying and discussing the steps that are involved in the process of responsible ethical decision-making. Critically discussing and further developing his views could be an appropriate point of departure for a contemporary ethic of responsibility (cf. De Villiers 2011; Tödt 1977, 1988a, 1988b).

\section{Acknowledgements Competing interests}

The author declares that he has no financial or personal relationships which may have inappropriately influenced him in writing this article. 


\section{References}

Baumgarten, E., 1964, Max Weber: Werk und Person, JCB Mohr (Paul Siebeck), Tübingen.

Bayertz, K., 1995, 'Eine Kurze Geschichte der Herkunft der Verantwortung', in Verantwortung: Prinzip oder Problem?, pp. 3-71, Wissenschaftliche Buchgesellschaft, Darmstadt.

Bayertz, K., 2004, Warum überhaupt moralisch sein?, Beck, Munich.

De Kruijf, G.C., 1994, Waakzaam en nuchter: Over christelijke ethiek in een democratie, Ten Have, Baarn.

De Villiers, D.E., 2011, 'An ethics of responsibility reading of Eduard Tödt's theory on the formation of moral judgements', in L. Hansen, N. Koopman \& R. Vosloo (eds.), Living theology: Essays presented to Dirk J. Smit on his sixtieth birthday, pp. 468480 , Bible Media, Wellington.

De Villiers, D.E., 2012, 'Do the prophetic and reformist approaches in Christian Ethics exclude one another? A responsibility ethics attempt at reconciliation', In die Skriflig/In Luce Verbi 46(1), Art. \#38, 8 pages. http://dx.doi.org/10.4102/ids. v46i1.38

Goldman, H., 1988, Max Weber and Thomas Mann: Calling and the shaping of the self, University of California Press, Berkeley, CA.

Habermas, J., 2005, Zwischen Naturalismus und Religion: Philosophische Aufsätze, Suhrkamp, Frankfurt am Main.

Habermas, K., 2002, Religion and rationality, Polity Press, Cambridge.

Lassman, P. \& Speirs, R. (eds.), 1994, Weber: Political writings, Cambridge University Press, Cambridge.

Mommsen, W.J., 1989, The political and social theory of Max Weber: Collected essays, Polity Press, Oxford.

Müller, H.-P., 2007, Max Weber: Eine Einführung in sein Werk, Böhlau Publishers, Cologne.
Roth, G., 1984, 'Max Weber's ethics and the peace movement today', Theory and Society 13(4), 491-511. http://dx.doi.org/10.1007/BF00156900

Schluchter, W., 1996, Paradoxes of modernity: Culture and conduct in the theory of Max Weber, transl. N. Solomon, Stanford University Press, Stanford, CA.

Schweiker, W., 2000, 'Responsibility in the world of Mammon: Theology, justice and transnational corporations', in M.L. Stackhouse \& P.J. Paris (eds.), God and globalization: Religion and the powers of the common life, vol. 1, pp. 128-139, Trinity Press International, Harrisburg, PA.

Shapcott, R., 2010, International ethics: A critical introduction, Polity Press, Cambridge.

Tödt, H.E., 1977, 'Versuch zu einer Theorie ethischer Urteilsfindung', Zeitschrift für Evangelische Ethik 21, 81-93. http://dx.doi.org/10.14315/zee-1977-0110

Tödt, H.E., 1988a, 'Versuch einer ethischen Theorie sittlicher Urteilsfindung', in idem. Perspektiven theologischer Ethik, pp. 21-48, Chr. Kaiser Verlag, Munich.

Tödt, H.E., 1988b, 'Die Zeitmodi in ihrer Bedeutung für die sittliche Urteilsfindung', in idem. Perspektiven theologischer Ethik, pp. 49-84, Chr. Kaiser Verlag, Munich.

Weber, M., 1949, '“Objectivity” in social science and social policy', in E.A. Shils \& H.A. Finch (transl. \& eds.), Max Weber on the methodology of the social sciences, pp. 49-112, The Free Press, Glencoe, IL.

Weber, M., 1958, Gesammelte politische Schriften, 2nd edn., J.C.B. Mohr (Pau Siebeck), Tübingen.

Weber, M., 1968, Gesammelte Aufsätze zur Wissenschaftslehre, 3rd edn., J.C.B. Mohr (Paul Siebeck), Tübingen.

Weber, M., 1975, Max Weber: A biography, transl. H. Zohn, John Wiley \& Sons, New York, NY.

Weber, M., 1994, 'The profession and vocation of politics', in P. Lassman \& R. Speirs (eds.), Weber: Political writings, pp. 309-369, Cambridge University Press, Cambridge.

Weber, M., 2004, The essential Weber: A reader, Routledge, London. 